\title{
We Continue to "Manage": A Transformational Leadership Perspective on Social Work Management in the NPO Sector in South Africa?
}

\author{
Nevashnee Perumal \\ Department of Social Development Professions, Nelson Mandela Metropolitan University, South Africa \\ *Corresponding Author: Nevashnee.perumal@nmmu.ac.za
}

\begin{abstract}
Although South Africa's policies have evolved significantly since the attainment of democracy in 1994, social work management education and training remains visibly neglected and leadership as a subset of social work management appears to be less prominent in social work practice. Social workers at the frontline, middle and top management levels in the NPO sector have continued to deliver services and uplift marginalised communities despite not having formal management qualifications in social work. This paper suggests ways of strengthening management capacity in the Non-Profit Organisation sector from a transformational leadership perspective based on Burns (1978) and Bass and Avolio's (1994) work, so that social workers may continue to "manage" despite the macro level challenges they face in the wake on evolving policies in South Africa.
\end{abstract}

Keywords Management, Transformational Leadership, Social Development, NPO, Frontline Social Worker, Social Change

\section{Introduction to Social Work Management and Leadership in South Africa}

In South Africa, management is considered in many instances, a by-product in social work practice in both the private as well as public sectors, meaning that it happens incidentally and not intentionally especially due to the crisis nature of social work and the emphasis on direct service delivery (RSA, 1997a). According to Lewis, Packard \& Lewis (2012) and Menefee (2004), managers need a good deal of education, training and development due to the multitude of technical and interpersonal skills necessary to perform management tasks in social work. What makes social work management unique is that all social work managers are professionally trained, qualified, registered social workers, however, not specifically trained in management per se. Furthermore, there is no formal management training provided at Higher Education Institutions (HEIs) in social work, except perhaps for a few undergraduate modules in the entire four year social work qualification (Brilliant, 1986, Engelbrecht, 2013, South African Qualifications Authority, n.d). The 27 exit level outcomes upon which the South Africa's Bachelor of Social Work degree (BSW) is scaffolded, further indicates a clear absence of leadership as a core subsection of management in the social work programme (South African Qualifications Authority, n.d). In the South African context, social work management training and development is relatively diluted due to the challenges of an inequitable apartheid past which left communities socially disabled. Hence, the need to capacitate the social work profession at the frontline (direct social work services) gained prominence by the government providing scholarships to undergraduate students wishing to study social work, thereby increasing the number of social workers being trained to deliver frontline services. Ironically, social work management training and development was not identified as a priority. The irony lies in the fact that the more new frontline social workers entering the field, the more supervision, management and leadership is required to guide, support and further educate them in practice (Engelbrecht, 2012; Patel, 2005; RSA, 1997a; RSA, 2006; Russell \& Swilling, 2002).

\section{What is Social Work Management and Why is Leadership Necessary?}

Management in human services, of which social work is a part, is defined according to Lewis, Packard and Lewis (2012:4) as: the process of making a plan to achieve some end, organising the people and resources needed to carry out the plan, encouraging the helping workers who will be asked to perform the component tasks, evaluating the results and then revising the plans based on this evaluation (Lewis, et al, ISSN: 2332-6840 (Online) 2332-6832 (Print) Copyright (C) 2015 by authors, all rights reserved. Authors agree that this article remains permanently open access under the terms of the Creative Commons Attribution License 4.0 International License 
2012:4). Furthermore, various authors, such as Nel (2014); Austin \& Hopkins (2004); Manning (2003) and Lewis, et al (2012), concur that the four main management functions in social work are the following: planning, organising, leading and controlling; which is based on Henri Fayol's (1949) Universal Management Principles school of thought (Fayol, 1949).

As indicated in the definition of management, leadership is inherent within management functions. According to Northouse (2012), scholars have struggled with an explicit definition of leadership. There have been various attempts by different authors to define leadership, yielding increasing depth, yet differing views (Senge, 1999; Grint, 2005; Gill, 2006). Furthermore, there have been attempts by other authors (Kotter, 1990; Bennis \& Nanus, 1985) to differentiate management from leadership. In the absence of an explicit definition, leadership may be understood as encompassing themes such as being focused on the future or having a vision, dealing with instability and uncertainty, crafting ways in order to bring about change and initiating, sustaining and maintaining momentum and stability during the change process. Essentially, although leadership is a subset of management (Lawler \& Bilson, 2010), both management and leadership are required in equal measure to keep social service organisations functioning optimally.

\section{South Africa's Transition to A Social Development Approach to Welfare and its Implications for Social Work Management}

South Africa's twenty year old liberation from apartheid places it, metaphorically, in the youth stage of development (Zastrow \& Kirst-Ashman, 2010) in terms of age and level of maturity. Consistent with this stage of development, is a "restlessness", attempting to find an identity, maintaining independence and asserting itself, nationally and internationally. In South Africa's case, this identity may be likened to the transformation agenda, arguably possessing a dynamic momentum, under the current African National Congress (ANC) led government. Various policies viz. the Reconstruction and Development Programme (RDP, 1994), Growth Employment And Redistribution (GEAR) strategy (RSA, 1996), the New Growth Path (RSA, 2011) and the most recent National Development Plan (NDP) (National Planning Commission, 2012) which all have a social development focus, have underpinned this transformation agenda. The common thread running through these policies is the aim to improve service delivery by making services more accessible and responsive to the needs of the vast majority of the population (DSD, 2004; RSA, 1997a).

For the South African welfare sector, which is a constituent of the social services sector (other sectors being: health, housing, education and environmental sectors), the
White Paper for Social Welfare (RSA, 1997a), born of the RDP, committed social service providers to adopt the social development approach to welfare. This, as a result of a flawed social welfare system in South Africa in its apartheid past, which subscribed to residual and institutional models of service delivery (Patel, 2005; Patel, Schmid \& Hochfeld, 2012; Rautenbach \& Chiba, 2010). The residual and institutional models subscribed to offering preferential services to minority privileged populations based on "stop-gap" measures and social security only (Midgely, 1995; Gray, 2008; Patel, et al., 2012). The social development approach, on the other hand, was anticipated to accelerate transformation by addressing race, class, gender and spatial imbalances because of its macroeconomic focus, emphasizing the interdependence between social and economic development (Patel, 2005; Patel, 2009; Gray, 2008; Midgely, 1995; Weyers, 2013; Rautenbach \& Chiba, 2010). Emanating from the social development approach was the term developmental social work which authors such as Patel (2005), Gray (2008) and Rautenbach \& Chiba (2010) contexualised as social work services being geared towards holistic, planned intervention which places human and social concerns at the centre of social welfare policy and planning. Developmental social work is strengths based and further geared towards bringing about social change using a systems approach (focusing on the person and environment and the interaction between the two) and based on the principles of social justice, equality, ubuntu, democracy and social change.

The implementation of developmental social work created new demands on an already overstretched public as well as private social welfare sector (Rankin \& Engelbrecht, 2014) since this approach dictated a shift in the culture and managerial practices of organisations rendering welfare services, to expand their services in order to reach less developed, under resourced and more marginalised communities (DSD, 2012). Ultimately, social work practice and its alignment to professional social work goals rest on the shoulders of social service managers (Patel, 2014). This author contends that the vision of organisations needed to remain intact however, organisations needed to conduct internal audits of a qualitative nature in order to respond favourably to the social developmental approach. Thus it is a clear indication that management capacity within social service organisations, especially within the established NPO sector, needs to be strong so that it may be receptive to the needs and challenges presented by the social development approach (Patel, 2014; Habib \& Taylor, 1999; Habib \& Kotze, 2002; Suraj-Narayan, 2010).

\section{The South African Non-profit Organisation (NPO) sector}

An NPO is defined, in terms of Section 1 of the NPO Act (Act No 71 of 1997), as a trust, company or other association 
of persons established for a public purpose and of which its income and property are not distributable to its members or office bearers except as reasonable compensation for services rendered (RSA, 1997b). Non-governmental organisations (NGOs) and community based organisations (CBOs) are collectively known as Non Profit Organisations (NPOs) (RSA, 1997b:2). Established NPOs are seen as larger, well organised and well resourced NPOs who are further seen to possess the capacity to transfer skills to emerging NPOs. They possesses the management capacity and financial accounting structures to enter into contracts with government and private funders to enhance their economic sustainability. Established NPOs are regulated, largely urban and are represented by national councils that are umbrella bodies of welfare organisations (DSD, 2005; Russell and Swilling, 2002; Patel, 2009; Patel, et al., 2012; Anheier, 2005).

It was anticipated that the forerunners in implementing the social development approach would be the National Department of Social Development, who would lead by example, so that other social work service providers such as the Non Profit Organisations sector (NPO) could follow suit. However, the National Department of Social Development found themselves equally challenged and struggling to meet the demands of the social development approach and responded by formulating the Integrated Service Delivery Model (RSA, 2006) which provided a framework to support the social development approach in terms of "what" must be done and "by whom", the whom being: national department of social development, provincial departments of social development, regional offices, local offices, local government, national bodies, NGOs, CBOs and private practitioners, however it remained silent on the "how" it must be done and "with what specific resources" (RSA, 2006). Since government is highly bureaucratised, it made political sense to widen their contracts with the NPO sector to deliver on this constitutional mandate of providing the best possible services to the poorest and most vulnerable sectors of society.

Since many established NPOs possess negligible bureaucracy in comparison to the National Department of Social Development, and although better placed to register formally, according to the NPO Act (Act No 71 of 1997), this sector still experienced a crisis (RSA, 1997b) when faced with registration. The crisis was around restructuring in order to deliver inclusive services to areas and populations that they avoided in the apartheid past. The NPO sector was therefore forced to regroup and re-emerged from this crisis, more streamlined and in reduced numbers, many forging partnerships with emerging NPOs and CBOs, where little structure and capacity existed, so that they could meet the requirements of registration as per the NPO Act 71/1997 (RSA, 1997b) thereby ensuring their survival (Habib \& Kotze, 2002). Hence, management at all levels in social work viz. boards of directors, top managers, middle managers as well as frontline social workers needed to reassess their prevailing strategies in terms of direct services as well as management, and align these to the social development approach. In other words, in to remain responsive to the clients and communities they served, frontline social workers, middle managers and top managers in the established NPO sector, needed to transform their intervention strategies as well as their management roles on a micro, meso and macro level (Patel, 2014).

Having alluded to the challenges faced by the NPO sector, on a positive note in terms of service delivery, established NPOs were better placed to transform their governing boards consisting of voluntary membership and merging with emerging NPOs and CBOs, made it easier to show diversity in terms of race and gender. This made them more representative of the poor, mainly non-white communities that they now had to serve (Russell \& Swilling, 2002). Although subsidised by the state, NPOs depend on donor funding for their existence which creates a greater need for monitoring and evaluating progress against their outputs for funding. The state also has different funding levels and reporting requirements which placed added pressure on the management structures within NPOs (Patel, 2009), where previously social workers focused on leading and managing change, now they focus on survival by accounting to government as well as to funders (Habib \& Kotze, 2002). The ethical paradox lies in the NPO sector delivering services to the "poorest of the poor", yet not accounting to this population but rather to their financiers.

\section{Multilevel Social Work Management Tasks}

Although the frontline social worker may not commonly be seen as performing management (and/or leadership functions), according to Perlmutter \& Crook (2004), his/her role as a direct service social worker in an established NPO often involves recruiting and training volunteers, attending management committee meetings, providing input on the organisation's constitution, mentoring and contracting with emerging organisations, evaluating business plans, writing funding proposals and giving effect to the projects that funds are requested for.

Similarly, middle managers were traditionally seen to set the goals for individual departments or teams. This level of management was further, mainly, responsible for mobilising frontline social workers to achieve organisational and individual goals (Rankin \& Engelbrecht, 2014; Lewis et al, 2012). However, in order to align with the social development approach, it has become commonplace in the South African established NPO sector, for middle managers to vacillate between front line services and middle management due mainly to the lack of human resource capacity in the NPO sector but also working in unison with 
frontline social workers to achieve the organisational vision. Middle managers also often find themselves fluctuating between the middle management and top management level, being tasked with a variety of managerial and leadership responsibilities, such as vision crafting, advocacy, ensuring the organisations financial stability, etc. These roles clearly exceeding the traditional three-pronged supervisory function of supervising social workers as propounded by Kadushin (1992) viz. educative, supportive and administrative functions.

The top management level which consists of senior managers, assistant directors and directors find themselves making and taking strategic decisions that affect the overall functioning of the organisation and the direction that the organisation will take. Consistent with this vision crafting, top managers develop policies which provide a compass for the organisation so that middle managers may develop programs that frontline staff will implement with clients and communities. These roles being consistent with leadership (Perlmuter \& Crook, 2004; du Brin, 2013; Manning, 2003; Fisher, 2009).

Although the term management is often misinterpreted as only referring to middle managers and top level managers such as supervisors and directors; frontline social workers also perform management functions (Perlmutter \& Crook, 2004). Authors such as Rankin and Engelbrecht (2014) and Lewis, et al (2012) posit that there is almost universal consensus on the four main functions of management viz. planning, organising, leading and control informed by the work of Henri Fayol in 1949. In managing daily duties, social workers constantly make plans to achieve some end, they organise the people and resources needed to carry out the plan, they encourage and support the helping workers who perform the component tasks and finally the results are evaluated which leads to a revision of future plans, ultimately enhancing service delivery. This definition encompasses the management roles of social workers at multiple levels of social work service delivery viz. frontline or direct services, middle management and top management. Simply put, all social workers are managers (Coulshed \& Mullender, 2006; Austin \& Hopkins, 2004; Perlmutter \& Crook, 2004). In executing management roles, social workers are further expected to possess technical, human and conceptual skills, which naturally occur in varying intensities at the various levels of management. The management tasks that social workers undertake include: workload management, time management, information management, risk management, change management, programme and project management, human resources management and financial resources management (Rankin \& Engelbrecht, 2014).

\section{Leadership as a Core Component of Social Work Management}

In order to create synergy within and across the multiple levels of management, a strong leadership component is necessary (Lewis, et al, 2012; Austin \& Hopkins, 2004; Manning, 2003). In the past, leadership was considered a function reserved for top management alone (Austin \& Hopkins, 2004) and referred to a strong external force being brought into an organisation in order to implement change and increase organisational effectiveness (Lawler, 2007; Lawler \& Bilson, 2010). However, social work managers at all levels fulfil leadership roles especially against the backdrop of the social development approach. They help keep the organisation and all staff focused on key organisational outcomes and processes necessary to achieve these outcomes (Midgely, 1995; Engelbrecht, 2014). It is common for social workers at the various levels of management to be called upon to represent the organisation on task teams, working groups and management boards (Wimpfheimer, 2004) meaning that social workers are placed in leadership positions where they are expected to articulate a vision as it relates to service users and communities. Since social workers in the established NPO sector, operate with a greater degree of autonomy due to their organisational structures not maintaining very rigid bureaucracy, they are often found in a position of helping the organisation to respond to environmental as well as internal changes by constantly adapting programs and organisational processes for increased organisational effectiveness (Austin \& Hopkins, 2004).

This, therefore indicates a need for a strengthened and somewhat formalised relationship between leadership and management in social work since social workers at the multiple levels of management find themselves advocating for social change (Hepworth, et al, 2010; Zastrow, 2010). All social workers, and by implication all social work managers, are trained to be agents of social change (Sewpaul, 2013). More especially in the South African social work context, where transformation (change) underpins developmental social work and occupies a prominent space in the social development approach to welfare (Patel, 2005; Rautenbach \& Chiba, 2010).

\section{Social Change and the Value of Transformational Leadership in Social Work Management}

Social change is consistent with theories of leadership generally; and transformational leadership specifically. Transformational leadership is characterised by followers performing beyond expected levels of performance as a result of the leader's influence (Bass \& Avolio, 1994; Manning, 2003; Gill, 2006; Lawler, 2007; Hickman, 2010; Northouse, 2012) and incorporates values and ethics as one of the core elements of the perspective (Yukl \& Lepsinger, 2004; Manning, 2003). Furthermore, the focus on leading is on enhancing relationships, building community and empowering marginalised communities which are core to; 
and consistent with social work training (Manning, 2003; Zastrow \& Kirst-Ashman, 2010; Hepworth, et al., 2010; Zastrow, 2010) implying the synergy between social work management and leadership (Yukl \& Lepsinger, 2004; Lawler, 2010; Lewis et al, 2012). A synergy which is further consistent with the principles of the social development approach.

According to Hellriegel, et al (2012), the early models of leadership such as the personality traits models, the contingency models and situational models did not outwardly address ways in which leaders could influence followers. These models appeared to be based on the power to change and/or hold an organisation together, being vested in a few top level employees. Many top managers around the world believe that a partnership needs to exist at all levels in an organisation so as to maximise services and productivity (Gill, 2006; Yukl, 2010; Hickman, 2010; Northouse, 2012), in this case the frontline, middle and top management levels in the social work profession. Against the backdrop of the social development approach to social welfare in South Africa, where sustainable economic growth and development is prioritised for populations in need, the belief that every individual has the ability to influence another is paramount in order to effect social change (Midgely, 1995; Patel, 2005; Patel, 2014; Patel, et al, 2012;). Although South Africa has made many strides following the attainment of democracy in 1994, the country generally and social work in the country specifically, is still challenged. As easy as it is for communities to give up based on poverty and unemployment similarly, it is easy for social workers to give up based on a lack of motivation which is precipitated by high caseloads, lack of resources to provide services and poor income in the profession, to name a few social work challenges. The resultant effects being burnout and social workers ultimately leaving the country for greener pastures (Hawkins \& Shohet, 2012; Engelbrecht, 2012).

In order for social workers in the established NPO sector to give effect to developmental social work, which is underpinned by the social development paradigm and directly linked to the country's transformation agenda (Patel, 2005; Midgely, 1995; Rautenbach \& Chiba, 2010) the transformational leadership perspective which is layered on a strengths base, provides the frame from which social work management roles at the multiple levels may be built on and strengthened. The transformational leadership perspective has the following core constructs: "leaders stimulating interest among colleagues and followers to view their work from new perspectives; generating an awareness of the mission or vision of the team and organisation; developing colleagues and followers to higher levels of ability and potential and; motivating colleagues and followers to look beyond their own interests toward those that will benefit the group" (Bass \& Avolio, 1994:2).

The transformational leadership perspective therefore proposes that leaders and followers work in unison to accomplish shared goals; they increase each other's morale and motivation, aspire to greater accomplishments and view challenging situations with creative problem solving lenses (Burns, 1978, Bass \& Avolio, 1994; Manning, 2003; Yukl \& Lepsinger, 2004; Lewis, et al, 2012; Hellriegel, et al, 2012). Hence, for communities transformational leadership proposes the recognition of every individual's circle of influence irrespective of socio economic status. For the social work profession transformational leadership provides motivation in the form of camaraderie and the belief in one's self to achieve beyond expectations individually and collectively, which are some of the key ingredients to successful management in social work. Transformational leadership embodies elements of hope in relatively hopeless situations, such as those South African social workers and communities find themselves in, providing metaphorical spaces for motivation to come from within, and which may further be spread vertically and horizontally within organisations.

Viewing social work management from a transformational leadership perspective may be argued as being least restrictive and most empowering for social work management in South Africa, taking the country's youth stage of democratic development into consideration, especially with the social development approach being at the forefront of this stage of development. This leadership perspective dismantles traditional authority, which was apparent in the residual and institutional welfare approaches used in South Africa in the past and now subscribes to empowering people, according to the present social development approach to social welfare in South Africa. A transformational leadership perspective intends for social workers, in their daily management roles, to generate more meaning in their work and ultimately in the lives of service users (bringing about social change) (Tichy \& Devana, 1986; Zastrow, 2010; Hepworth, et al, 2010; Northouse, 2012; Patel, 2014). Manning (2003) postulates that transformational leadership is not restricted to any specific level of management nor position within an organisation, therefore alluding to its use by the frontline, middle and top management levels in social work practice, in the established NPO sector.

\section{Concluding Remarks}

From the aforegoing, it is apparent that management in social work exists on multiple levels in the established NPO sector; and within these management roles social work managers further fulfil covert leadership roles. However, against the backdrop of the enormous demands of the social development approach, with strained resources, capacity and direction; the transformational leadership perspective provides a strengths base from which to manage daily social work tasks. However, since management is a by-product in the social work profession in South Africa generally, and in 
the established NPO sector specifically, it has not gained much research prominence. In the past twenty years, in the new democratic dispensation, the limited research done on management in social work focuses mainly on the middle manager. Similarly, leadership studies done, focus mainly on the top manager (Bailey, 1995; Booyens, 1997; Maleka, 2004; Unite, 2000). This points to a need for research which explores the management roles of social workers at the multiple levels in the established NPO sector and; considers the notion that as agents of social change, social workers fulfil leadership roles which may best be understood and nurtured from transformational leadership perspective, for the purposes of sustainable social and economic growth for marginalised South Africans.

\section{Acknowledgement}

The author wishes to acknowledge Prof Lambert Engelbrecht's (Department of Social Work, Stellenbosch University) mentorship in conceptualizing this article.

\section{REFERENCES}

ANHEIER, H. 2005. Non-profit organisations. Theory, management, policies. New York: Routledge Publishers.

AUSTIN, M.J. \& HOPKINS, K.M. (eds) 2004. Supervision as Collaboration in the Human Services: Building a Learning Culture. Sage Publications Inc. Thousand Oaks.

BAILEY, L. 1995. A comparative study of the problems and challenges of women in social work. Unpublished doctoral dissertation. Durban: University of Durban-Westville.

BASS, B.M. \& AVOLIO, B.J. (eds) 1994. Improving Organisational Effectiveness through Transformational Leadership. Sage Publications Inc. Thousand Oaks, California.

BOOYENS, M.G. 1997. Social work and social development management training for non-governmental organisations (NGOs). Unpublished doctoral dissertation. Port Elizabeth: Nelson Mandela Metropolitan University.

BRILLIANT, E. L.1986. Social Work Leadership: A Missing Ingredient? Social Work. September-October, 325-331.

BRYMAN, A., COLLINSON, D., GRINT, K., JACKSON, B. \& UHL-BIEN, M. (eds) 2011. The SAGE Handbook of Leadership. Sage Publications Ltd. Olivers Yard. London.

BURNS, J.M. 1978. Leadership. Harper Torchbooks. New York.

COULSHED, V. \& MULLENDER, A. 2006. Management in Social Work. Basingstoke: Palgrave MacMillan.

DSD (DEPARTMENT OF SOCIAL DEVELOPMENT). 2012. National NPO summit: transformation of welfare services sector, 14-17 Aug 2012) [Online] Available: http://www.dsd.gov.za/npo/index2.php?option=com_docman\&tas $\mathrm{k}=$ doc_view\&gid=133\&Itemid=39. Unpublished article. [Accessed: 22.01. 2014]
DSD (DEPARTMENT OF SOCIAL DEVELOPMENT). 2005. Policy on the financial awards to service providers. Pretoria: Department of Social Development.

DSD (DEPARTMENT OF SOCIAL DEVELOPMENT). 2004. Recruitment and retention strategy for social workers. Pretoria: Department of Social Development.

DU BRIN, A.J. 2013. Principles of Leadership. $7^{\text {th }}$ edition. South Western Cengage Learning.

ENGELBRECHT, L.K. 2012. The neglected agenda of social work management and supervision: Issues and challenges. Joint World Conference on Social Work and Social Development. Stockholm: Sweden.

ENGELBRECHT, L.K. 2013. Social Work Supervision and Frameworks: Playing Notes or Making Music. Social Work/Maatskaplike Werk, 49(4): 456-467.

ENGELBRECHT, L.K. (ed) 2014. Management and supervision of social workers: Issues and challenges within a social development paradigm. Andover: Cengage Learning EMEA Limited.

FAYOL, H. 1949. General and industrial management. Translated by Storrs, C. Sir Isaac Pitman \& Sons. London

FISHER, E.A. 2009. Motivation and Leadership in Social Work Management: A Review of Theories and Related Studies. Administration in Social Work, 33(4): 347-367. Doi: 10.1080/03643100902769160.

GILL, R. 2006. Theory and Practice of Leadership. SAGE.

GRAY, M. 2008. The progress of social development in South Africa. International Journal of Social Welfare, 15 (1):53-64.

GRINT, K. 2005. Problems, problems, problems: The social construction of 'leadership'. Human Relations, 58(11): 1467-1494. DOI: $10.1177 / 0018726705061314$.

HABIB, A. \& KOTZE, H. 2002. Civil Society, Governance and Development in an Era of Globalisation. [Online] Available: http://www.lead.colmex.mx/docs/s4/02 sociedad $\% 20$ civil $\% 20 \mathrm{y} \%$ 20ONG/HABIB_civil\%20society\%20governance $\% 20$ and $\% 20 \mathrm{dev}$ elopment.pdf [Accessed: 17.03.2014]

HAWKINS, P. \& SHOHET, R. 2012. Supervision in the Helping Professions. $4^{\text {th }}$ edition. Open University Press McGraw Hill. England.

HELLRIEGEL, D., SLOCUM, J., JACKSON, E., LOUW, L., STAUDE, G., AMOS, T., KLOPPER, H.B., LOUW, M., OOSTHUIZEN, T., PERKS, S. \& ZINDIYE, S. (eds) 2012. Management. Oxford University Press Southern Africa. Cape Town.

HEPWORTH, D.H., ROONEY, G.D., STROM-GOTTFRIED, K. \& LARSEN, J.A. 2010. Direct Social Work Practice: Theory and Skills. $8^{\text {th }}$ edition. Brooks/Cole, Cengage Learning.

HICKMAN, G.R. 2010. Leading Change in Multiple Contexts: Concepts and practices in Organizational, Community, Political, Social and Global Change Settings. Sage Publications Inc. Thousand Oaks, California.

KADUSHIN, A. 1992. Supervision in Social Work. $3^{\text {rd }}$ edition. New York: Columbia University Press.

KOTTER, J. P. 1990. A force for change: How leadership differs 
from management. Free Press: New York.

LAWLER, J. 2007. Leadership in Social Work: A Case of Caveat Emptor? British Journal of Social Work, 37:123-141. Doi:10.1093/bjsw/bch404

LAWLER, J. \& BILSON, A. 2010. Social Work Management and Leadership: Managing Complexity with Creativity. Routledge. Abingdon, Oxon

LEWIS, J.A., PACKARD, T. \& LEWIS, M.D. 2012. Management of human service programs $\left(5^{\text {th }}\right.$ ed). London: Brooks $/$ Cole CENGAGE Learning.

MALEKA, E.D. 2004. Social work management and leadership in a democratic South Africa : perceptions of social workers in senior positions employed in non-governmental organisations. Unpublished masters dissertation. Johannesburg: University of Witwatersrand.

MANNING, S.S.M. 2003. Ethical Leadership in Human Services: A Multidimensional Approach. Pearson Education Inc. Allyn \& Bacon. United States of America.

MENEFEE, D. 2004. The Managerial Roles of the Supervisor. In: AUSTIN, M.J. \& HOPKINS, K.M. (eds) Supervision as Collaboration in the Human Services: Building a Learning Culture. Sage Publications Inc. Thousand Oaks.

MIDGELY, J. 1995. The development perspective in social welfare. New York: Sage Publications.

NATIONAL PLANNING COMMISSION. 2012. National Development Plan 2030: our future - make it work. Pretoria. Department: The Presidency.

NEL, H. 2014. Management functions. In: ENGELBRECHT, L.K. (ed) Management and supervision of social workers: Issues and challenges within a social development paradigm. Andover: Cengage Learning EMEA Limited.

NORTHOUSE, P.G. 2012. Introduction to Leadership: Concepts and Practice. $2^{\text {nd }}$ edition. Sage Publications Inc. Thousand Oaks. California.

PATEL, L. 2005. Social welfare and social development in South Africa. Goodwood: Oxford University Press.

PATEL, L. 2009. The Character of Social Care in the Non-Profit Sector in South Africa. United National Research Institute for Social Development. Centre for Social Development in Africa. University of Johannesburg.

PATEL, L., SCHMID, J. \& HOCHFELD, T. 2012. Transforming Social Work Services in South Africa: Perspectives of NPO managers. Administration in Social Work, 36(2): 212-230. DOI: 10.1080/03643107.2011.567321.

PATEL, L. 2014. Social development, management and supervision of social work professionals. In: ENGELBRECHT, L.K. (ed) Management and supervision of social workers: Issues and challenges within a social development paradigm. Andover: Cengage Learning EMEA Limited.

PERLMUTTER, F.D. \& CROOK, W.P. 2004. Changing Hats While Managing Change: From Social Work Practice to Administration. $2^{\text {nd }}$ edition. NASW Press. United States of America.
RANKIN, P. \& ENGELBRECHT, L.K. 2014. The context of management in social service organisations. In: ENGELBRECHT, L.K. (ed) Management and supervision of social workers: Issues and challenges within a social development paradigm. Andover: Cengage Learning EMEA Limited.

RAUTENBACH, J.V. \& CHIBA, J. 2010. Introduction. In: Nicholas, L., Rautenbach, J. \& Maistry, M. (eds) Introduction to social work. Claremont: Juta and Company Limited.

RDP (RECONSTRUCTION AND DEVELOPMENT PROGRAMME). 1994. Reconstruction and Development Programme: A Policy Framework. [Online] Available: http://www. polity.org.za/polity/govdocs/rdp/rdp.html [Accessed: 24.03.2014]

RSA (REPUBLIC OF SOUTH AFRICA). 1996. Growth, Employment And Redistribution: A Macroeconomic Strategy. National Treasury. [Online] Available:

www.treasury.gov.za/publications/other/gear/chapters.pdf [Accessed:24.03.2014].

RSA (REPUBLIC OF SOUTH AFRICA). 1997a. White Paper on Social Development 1997: Towards a new social Welfare Policy and Strategy for South Africa. Pretoria: Government Printers.

RSA (REPUBLIC OF SOUTH AFRICA). 1997b. Non-Profit Organisations Act 77. Pretoria: Government Printers.

RSA (REPUBLIC OF SOUTH AFRICA). 2006. Integrated service delivery model towards improved social services. Pretoria: Department of Social Development.

RSA (REPUBLIC OF SOUTH AFRICA). 2011. New Growth Path. Economic Development Department. [Online] Available: http://www.economic.gov.za/communications/publications/new-gr owth-path-series [Accessed: 21.03.2014].

RUSSELL, B. \& SWILLING, M. 2002. The size and Scope of the Non - Profit Sector in South Africa. Centre for Civil Society, University of Natal and the School of Public \& Development Management, University of the Witwatersrand.

SAQA. n.d. SOUTH AFRICAN QUALIFICATIONS AUTHORITY . Available:

http://regqs.saqa.org.za/viewQualification.php?id=23994.

Accessed [11.03.2014].

SENGE, P. 1990. The Fifth Discipline: The Art and Practice of the Learning Organization. New York: Doubleday Currency.

SEWPAUL, V. (editorial). 2013. Review of the International Definition of Social Work. Social Work/Maatskaplike Werk, 49(2): $\mathrm{x}$-xiv.

SURAJ-NARAYAN, G. 2010. Management and Administration. In: Nicholas, L., Rautenbach, J. \& Maistry, M. (eds) Introduction to Social Work. Claremont: Juta and Company Limited.

TICHY, N.M. \& DEVANNA, M.A. 1986. The Transformational Leader. John Wiley \& Sons Inc. United States of America.

UNITE, R.G. 2000. An analysis of social workers perceptions of the management of organisational transformation within Port Elizabeth district office of Social Welfare: A case study. Unpublished masters thesis. Port Elizabeth: Nelson Mandela Metropolitan University.

WEYERS, M. 2013. Towards the Reconceptualization of Social Welfare in South Africa: An Analysis of Recent Policy Trends. 
Social Work/Maatskaplike Werk, 49(4): 433-455.

WIMPFHEIMER, S. 2004. Leadership and Management Competencies Defined by Practicing Social Work Managers: An Overview of Standards Developed by the National Network for Social Work Managers. Administration in Social Work, 28(1): 45-56.

YUKL, G. 2010. Leadership in organisations. New Jersey: Pearson Publications.
YUKL, G. \& LEPSINGER, R. 2004. Flexible Leadership: Creating Value by Balancing Multiple Challenges and Choices. John Wiley \& Sons Inc. San Francisco.

ZASTROW, C.H. \& KIRST-ASHMAN, K.K. 2010. $8^{\text {th }}$ edition. Understanding Human Behaviour and the Social Environment. Brooks/Cole Cengage Learning. United States of America.

ZASTROW, C.H. 2010. The Practice of Social Work: A Comprehensive work text. $9^{\text {th }}$ edition. Belmont: Brooks/Cole, Cengage Learning. 